\title{
Tax Smoothing in the Presence of the Maastricht Constraint
}

\author{
David Duffy \\ National University of Ireland Galway
}

Address: Department of Economics,

National University of Galway,

Galway, Republic of Ireland.

Telephone: +35391493053

Fax: +35391524130

Email:_ david.duffy@nuigalway.ie 


\section{Abstract}

A sample of European Union countries are examined for evidence of tax smoothing over the period 1970-2005. Two testing procedures are applied to a single sample of countries to assess the consistency of evidence across testing methods. This study includes the application of a new data set to the tax smoothing question which provides an estimate of the temporary component of public expenditure. This study also argues that the application of the constraints imposed on fiscal policy in the Maastricht Treaty will affect the conduct of a tax smoothing policy. The effects of the Maastricht Treaty on tax smoothing behaviour are investigated.

Keywords; Tax smoothing, Maastricht Treaty, Fiscal Policy.

JEL classification; $\mathrm{H} 2, \mathrm{H} 6$ 


\section{Tax Smoothing in the Presence of the Maastricht Constraint}

\section{Introduction}

The aim of this paper is to elucidate upon the behaviour of fiscal authorities and to establish whether support can be found for Barro's tax-smoothing hypothesis in a sample of European Union countries in the post 1970 period. The approach taken in this study is to apply two testing methodologies to a single multi country sample of EU countries to establish what support if any is provided for the tax smoothing hypothesis. This is an interesting period to test for evidence of the tax smoothing hypothesis as it is a period which encompasses the adoption of the Maastricht Criteria and the subsequent Stability and Growth Pact in many of the sample countries. These supra-national budgetary institutional changes provide a unique opportunity to establish whether this constraint affects the evidence in support of the tax smoothing hypothesis in a cross country sample.

The tax smoothing hypothesis is developed upon the Ricardian view of the fiscal deficit as restated by Barro (1974). The Ricardian view contends that farsighted individuals plan their consumption expenditures not only over their own life cycles but that they are also linked to successive generations through altruistically motivated resource transfers. Individuals therefore face a consumption allocation decision out of dynastic resources (their own resources and those of successive generations). In such a framework budget deficits result in a transfer of the burden of taxation across time and leave dynastic resources unaffected. Therefore deficit policy does not matter. If these strict assumptions 
are to hold then why do fiscal deficits occur? Barro (1979) answered this question by arguing that optimal fiscal policy dictates that taxes should be set such that the distortionary costs of taxation are minimised. As such fiscal deficits arise as a result of temporary fluctuations in public expenditure. This is known as the tax smoothing approach to fiscal policy.

The approach to testing the tax smoothing hypothesis has evolved since it was first proposed and tested by Barro (1979, 1986 and 1987). Barro tested the taxsmoothing hypothesis indirectly by examining if its implications for the fiscal deficit were supported by the data. The fiscal deficit was modelled as depending on temporary public expenditure because permanent public expenditure was funded by current taxation. Sahasakul (1986) and Gupta (1992) tested the taxsmoothing hypothesis directly by modelling the tax rate $^{1}$ as depending on permanent public expenditure. Recent literature tends to test the hypothesis based on the argument in Roubini and Sachs (1989) that a simpler direct test of the hypothesis is to examine if the tax rate is stationary, e.g. Strazicich (2002). This paper uses (i) the Barro approach because it tests if tax-smoothing determines the fiscal deficit; and, (ii) the Roubini and Sachs approach because it is currently the most accepted test of the tax-smoothing hypothesis.

This paper represents progress on previous empirical work for several reasons. Firstly this paper adds to the literature by applying two different testing procedures to test for the tax-smoothing hypothesis over a single data period using a multi country sample. This is done to clarify some previous conflicting

\footnotetext{
${ }^{1}$ Defined as the public revenue-GDP ratio.
} 
results regarding whether the tax smoothing hypothesis holds or not. Secondly a dataset, obtained from the European Commission, which measures the temporary and permanent components of public expenditure, is applied here in testing for support of the tax smoothing hypothesis. This is in response to some of the criticisms levelled at Barro's (1986) estimates of temporary public expenditure by Modigliani (1986). The data used to capture temporary public expenditure in this paper is the cyclical component of public expenditure obtained from the European Commissions AMECO database.

The post 1970 period is an interesting period in which to test for evidence of the tax smoothing hypothesis. Tax smoothing suggests a particular pattern of debt accumulation in response to the financing of public expenditure shocks. This pattern of debt accumulation may be constrained by various institutional features in a nation. The post 1970 period encompasses the adoption of the Maastricht Criteria and the subsequent Stability and Growth Pact in many of the sample countries. These supra-national budgetary institutional changes provide a unique opportunity to establish whether this constraint affects the evidence in support of the tax smoothing hypothesis in the cross country sample. ${ }^{2}$ This paper also contributes to the literature by explicitly taking into account the effects of the Maastricht Treaty and subsequent Stability and Growth Pact on the tax smoothing hypothesis. This is achieved by allowing for a structural break in the testing procedures applied. Evidence of a structural break is taken as evidence

\footnotetext{
${ }^{2}$ Considine and Duffy (2006) hae argued that the Maastricht treaty has influenced debt accumulation patterns across both EMU and non-EMU countries by institutionalising an acceptable level of debt accumulation across countries.
} 
that the Maastricht Treaty and the subsequent Stability and Growth Pact matters for the behaviour of fiscal authorities. The question as to how it affects tax smoothing behaviour is also addressed.

This paper proceeds as follows, Section II will outline the fiscal policy implications of the tax smoothing hypothesis along with some of the testable implications arising from the this hypothesis as well as the findings of previous authors. Section III sets out the methodology applied in this paper while Section IV provides the results of this study. This paper is completed with some conclusions in Section V.

\section{The Fiscal Policy Implications of the Tax Smoothing Hypothesis}

Taking a Ricardian view of the fiscal deficit Barro's (1979) paper suggests that the optimal level of taxation is one that smoothes tax rates over time in order to minimise the distortionary costs of changing tax rates. The distortionary costs of taxation arise due to the distortionary costs of taxation on welfare. The marginal costs of these distortions are assumed to be an increasing function of the amount of resources taxed. Given this assumption Barro shows that the optimal level of taxation is one that is constant over time, while satisfying the long run balanced budget constraint given the present value of future expected public expenditure. It is this constant level of taxation that will minimise the distortionary effects of taxation and as such will be the least costly time path for taxation in the long run. 
Important implications arise out of this theory for the determination of the fiscal deficit. Tax smoothing requires that fiscal authorities hold the tax rate constant within the constraints of a long run balanced budget. However public expenditure shocks caused by events such as wars or recessions occur. The financing of any public expenditure shock will be determined by whether the expenditure shock is a temporary or permanent expenditure shock. Since the optimal rate of taxation is constant given anticipated levels of public expenditure, any positive expenditure shock, which is perceived to be temporary in nature, ought to be accompanied by a temporary fiscal deficit. Once the temporary expenditure shock has passed, public expenditure will revert to its permanent level. At this point the fiscal deficit will be eliminated and any accumulated debt will be cleared in the limit while the tax rate remains constant throughout. ${ }^{3}$ This ensures that the government budget constraint holds in the limit. A similar analysis can be applied to a temporary negative shock to public expenditure which according to the tax smoothing hypothesis will result in a temporary fiscal surplus. Correspondingly the tax-smoothing hypothesis implies that any permanent positive (negative) shock to public expenditure will be financed by a corresponding permanent increase (decrease) in taxation. Permanent expenditure shocks will have no effect on the fiscal deficit. ${ }^{4}$

\footnotetext{
${ }^{3}$ Because the government budget constraint is specified for an infinite horizon, for any temporary expenditure shock the change in the tax rate necessary for the budget constraint to hold in the limit will be very small.

${ }^{4}$ For a more detailed explanation of the tax smoothing hypothesis see ROMER (2001, p. 541547).
} 
The practical implications of the tax smoothing hypothesis are that a positive temporary public expenditure shock will result in a temporary fiscal deficit while a negative temporary public expenditure shock will result in a temporary fiscal surplus. On the other hand a positive permanent shock to public expenditure will be financed by an increase in tax rates, while a negative permanent government expenditure shock will result in a decrease in tax rates. Several testable hypotheses arise out of these practical implications of the tax smoothing approach to public finance. Two of these testing procedures are applied in this paper. The first of these tests focuses on the determinants of the fiscal deficit while the second testing approach focuses on the determinants of the tax rate.

According to the tax smoothing hypothesis the fiscal deficit ought to be determined by fluctuations in temporary public expenditure. Hence the first test of the tax smoothing hypothesis applied here examines if the fiscal deficit is determined by temporary public expenditure. Several papers by Barro (1979, 1986 and 1987) take this approach to investigating evidence of the tax smoothing hypothesis. These papers test the tax smoothing hypothesis by examining the link between temporary public expenditure and fiscal deficits for the UK using data from 1701-1918 and for the US for the period 1916-1982. All three of Barro's papers have shown support for the tax smoothing hypothesis.

The choice of data period in both Barro's US and UK studies is noteworthy. As regards the UK study it is important to ask why Barro stops his analysis of the UK data in 1918. This may be because the UK did not tax smooth since 1919. Indeed Cooley and Ohanian (1997) argue that the poor performance of the UK 
economy relative to the US since WWII is attributable to the fact that the UK moved away from tax smoothing to a policy of active fiscal management encouraged by the arguments of Keynes. In the US Barro's reasons for only examining the $20^{\text {th }}$ century data is due to difficulties in obtaining earlier period data, however it may also be the case that given that there was so much 'settling in' of policies and institutions during the $19^{\text {th }}$ century in the US that it is unlikely that they followed a tax smoothing policy. This paper extends the methodology applied by Barro to a cross country sample of European Union countries in the post 1970 period.

A second issue arising out of Barro's evidence is his construction of the temporary components of public expenditure. Modigliani (1986) critically evaluates Barro's (1986) US results by focusing on Barro's construction of the temporary component of public expenditure data series. When examining Barro's data for the two world war periods Modigliani argues that the amount of the temporary increase in public expenditure financed through borrowing is much lower than the tax smoothing hypothesis would suggest. Modigliani also argues that Barro's measure of permanent public expenditure is sensitive to temporary wartime expenditure. If permanent public expenditure is sensitive to temporary public expenditure then it becomes impossible to clearly identify tax smoothing behaviour.

This study addresses some of the issues raised by Modigliani regarding the data used in Barro's studies. The first point to note about temporary fluctuations in public expenditure in the present study is there are no wartime induced 
fluctuations. ${ }^{5}$ The post 1970 s period has largely been peaceful in the sample countries. Barro's data periods included both wartime expenditure fluctuations and cyclical expenditure fluctuations. Barro's data has the practical implication that wartime fluctuations dominate cyclical expenditure fluctuations. This study attempts to explain the fiscal deficit in terms of temporary expenditure fluctuations that are characterised by cyclical expenditure fluctuations only. The methodology used to estimate the cyclical component of public expenditure in this study is different from Barro's. Whereas Barro uses an econometric method ${ }^{6}$ to estimate the cyclical components of public expenditure the data used in this study estimates the cyclical component of public expenditure by applying the Hodrick-Prescott filter to estimate the output gap. The cyclical component of public expenditure is then estimated with reference to the output gap by applying the elasticity of public expenditure to GDP. The data for the cyclical component of public expenditure is obtained from the European Commission. Further details on the construction of the cyclical component of public expenditure are provided in European Commission, European Economy (2001).

A second method of testing the tax smoothing hypothesis, which is related to Barro's approach, focuses on the tax rate. ${ }^{7}$ This approach examines the tax smoothing hypothesis from the view point that the tax rate ought to be determined by permanent public expenditure. Sahasakul (1986) applies this

\footnotetext{
${ }^{5}$ Over a longer time horizon it could be argued that the post 1970 s peacetime period is characterised by negative temporary military expenditure.

${ }^{6}$ See Barro (1986) for an explanation.

${ }^{7}$ The tax rate is usually defined as public revenue as a share of GDP. Although in the studies by Sahasakul (1986) and Gupta (1992) a marginal tax rate is calculated.
} 
approach to test the tax smoothing hypothesis using data for the US over the period 1937-1982 and Gupta (1992) also uses this approach in testing the tax smoothing hypothesis for Canada over the period 1946-1984. Both Gupta (1992) and Sahasakul (1986) find that permanent public expenditure is significant in determining the tax rate.

A more direct approach to testing the tax smoothing hypothesis through an examination of the tax rate is also available. The tax smoothing hypothesis maintains that the tax rate ought to be set at time $t$, based on the current information available on present and future spending commitments, such that the government intertemporal budget constraint holds in the limit. Hence the tax rate at time t can be considered permanent and ought only to be changed in response to an unexpected permanent expenditure shock. Any changes in the tax rate ought to be unpredictable, given the current information set. As such the tax rate at time $\mathrm{t}$ ought to be determined by the tax rate in the previous period and a random error accounting for any shock that occurs. This data generating process is the definition of a unit root process. Therefore evidence of a unit root in the tax rate time series can be taken as support for the tax smoothing hypothesis.

Roubini and Sachs (1989) and Strazicich (2002) both apply the unit root testing approach to testing the tax smoothing hypothesis in a cross country sample of industrialised countries. Using a sample period from 1960-1985 for 15 OECD countries, Roubini and Sachs (1989) find that the hypothesis of a driftless random walk in tax rates is rejected in 12 out of the 15 countries tested. This is taken as evidence against the tax smoothing hypothesis as the drift term in the tax 
rate is evidence of an upward drifting tax rate in line with increasing public expenditure. However a drift term may still be present in the tax rate time series even if a tax smoothing policy is being followed. The upward drift in public expenditure during the Roubini and Sachs (1989) study is likely to have been unexpected by policy makers. If this upward drift in expenditure is seen as a permanent peacetime public expenditure increase, then an upward drift in the tax rate during the period will be consistent with tax smoothing. Also if the marginal cost function of the tax rate was decreasing over time then tax smoothing would be consistent with the finding of an upward drift in the tax rate. Strazicich (2002) also tests for the presence of a unit root in the tax rate data using central government revenue while allowing for the presence of a drift term. A group of 19 industrial countries are examined over the period 1955-1988. Both single equation and panel unit root tests are applied and neither of these tests can reject the null hypothesis of a unit root in 18 out of the 19 countries examined.

A fundamental implication of the tax-smoothing hypothesis is that no other variables besides permanent public expenditure should be capable of determining the tax rate. Similarly evidence that factors besides temporary public expenditure determine the fiscal deficit is accepted as evidence against the tax smoothing hypothesis. In an important contribution to the political economy of fiscal policy, Alesina and Perotti (1995) argue that tax smoothing cannot explain the public debt accumulation patterns in Europe over the 1970s and 1980s and instead they resort to political economy explanations. In this paper they emphasise the role of electoral systems, party structure, government fragmentation and political polarisation in determining the fiscal deficit. In a later paper, Alesina and Perotti 
(1999) place more emphasis on the role of fiscal institutions in explaining the fiscal deficit. Indeed policy makers have also recognised the importance of fiscal institutions in constraining the accumulation of public debt. The policy implications of this work are expressed in the Gramm-Rudman-Hollings budgetbalance amendment and the excess deficit procedure in the European Union's Maastricht Treaty and the subsequent Stability and Growth Pact.

The Maastricht Treaty agreed in December 1991 required that EU countries seeking entry to the second stage of European Monetary Union (EMU) must achieve a $60 \%$ of GDP debt target or be making a significant effort to reach this target by May 1998. The Treaty also requires a fiscal deficit of below 3\% of GDP. The imposition of this constraint on the actions of fiscal policy makers has had impact on fiscal policy in both EMU countries and beyond. Considine and Duffy (2006) have argued that the Maastricht Treaty has institutionalised the $60 \%$ debt target as a generally acceptable level of debt across countries. This has resulted in a change to cross country debt accumulation patterns. This change has resulted in a move away from explosive patterns of debt accumulation in several EU countries towards a more sustainable fiscal policy. This change in debt accumulation patterns is more consistent with tax smoothing. As such the UK, Denmark, Sweden, USA and Japan are included in the analysis here even though they are not bound by the Stability and Growth Pact. Ballabriga and MartinezMongay (2005) have also recognised the role of Maastricht in inducing a move towards sustainable policy in some EU countries. This present study recognises the imposition the Maastricht Treaty and subsequent Stability and Growth Pact on the evidence in support of the tax smoothing hypothesis in EU countries. 


\section{Testing the Tax Smoothing Hypothesis}

This paper applies two testing procedures to test for evidence of the tax smoothing hypothesis. In both testing procedures a structural break is included to allow for the effects of the Maastricht Treaty and subsequent Stability and Growth Pact on the behaviour of fiscal authorities in the post 1991 period. The first testing procedure focuses on the relationship between the fiscal deficit and the cyclical component of public expenditure. This test involves applying a model similar to that set out in Barro (1979, 1986 and 1987). This model is set up in equation 1 as follows

$1 \quad\left(\mathrm{~b}_{\mathrm{t}}-\mathrm{b}_{\mathrm{t}-1}\right)=\alpha_{0}+\alpha_{1}\left(\mathrm{~b}_{\mathrm{t}-1}\right)+\alpha_{2} \tilde{g}_{\mathrm{t}}+\sum_{i=1}^{k} \alpha_{3_{\mathrm{i}}}\left(\mathrm{b}_{\mathrm{t}-\mathrm{i}}-\mathrm{b}_{\mathrm{t}-\mathrm{i}-1}\right)+\mathrm{u}_{\mathrm{t}}$

Where $b_{t}$ is general government gross debt at the end of year $t$ expressed as a percentage of GDP. $b_{t}-b_{t-1}$ is the stock flow consistent fiscal deficit expressed as a percentage of GDP for year $t, \tilde{g}_{\mathrm{t}}$ is the cyclical component of public expenditure expressed as a percentage of GDP, $\alpha_{0}$ is an intercept term and $u_{t}$ is a white noise error term. The $\sum_{i=1}^{k} \alpha_{3 \mathrm{i}}\left(\mathrm{b}_{\mathrm{t}-\mathrm{i}}-\mathrm{b}_{\mathrm{t}-\mathrm{i}-1}\right)$ term represents lagged values of the stock flow consistent fiscal deficit which is included to remove any serial autocorrelation. Acceptance of the tax smoothing hypothesis requires that the estimated coefficient on the cyclical component of public expenditure is unity or close to unity.

To establish whether the effects of the Maastricht Treaty influenced the relationship between the cyclical component of public expenditure and the fiscal 
deficit two dummy variables are added to the model as shown in equation 2 below.

$$
2 \quad\left(\mathrm{~b}_{\mathrm{t}}-\mathrm{b}_{\mathrm{t}-1}\right)=\alpha_{0}+\mathrm{d}_{1}+\alpha_{1}\left(\mathrm{~b}_{\mathrm{t}-1}\right)+\alpha_{2} \tilde{g}_{\mathrm{t}}+\mathrm{d}_{2} \tilde{g}_{\mathrm{t}}+\sum_{i=1}^{k} \alpha_{3 \mathrm{i}}\left(\mathrm{b}_{\mathrm{t}-\mathrm{i}}-\mathrm{b}_{\mathrm{t}-\mathrm{i}-1}\right)+\mathrm{u}_{\mathrm{t}}
$$

The first dummy variable $d_{1}$ allows for the Maastricht Treaty to cause a shift in the intercept term while the second dummy variable $\mathrm{d}_{2}$ allows for the Maastricht Treaty to cause a shift in the slope coefficient on the cyclical component of public expenditure term. Both dummy variables take on a value of 0 in the period 1970 to the structural break, and a value of 1 otherwise. Failure to reject the joint hypothesis that these two dummy variables are equal to zero will be taken as evidence of a structural break in the model. A structural break can be taken as evidence that the Maastricht Treaty and subsequent Stability and Growth Pact were significant in altering the behaviour of fiscal authorities by altering the relationship between the fiscal deficit and the cyclical component of public expenditure. Allowing for a structural break, support for the tax smoothing hypothesis now requires that $\alpha_{2}=1$ in the pre structural break period and that $\alpha_{2}$ $+\mathrm{d}_{2}=1$ in the post structural break period. Dummy variables are applied recursively from 1991 to 1994 to establish if the Maastricht Treaty changes the relationship between temporary public expenditure and the fiscal deficit.

The second set of testing procedures applied in this paper focuses on the implications of the tax smoothing hypothesis for the tax rate. Three different testing procedures are applied to test whether the tax rate follows a unit root process. Three tests for a unit root are applied in this paper due to the importance of the accuracy of these tests for the hypothesis under investigation. The first of 
these unit root tests is the Augmented Dickey Fuller (ADF) test. The second test applied is the Phillips-Perron (PP) (1988) test. This test is included as it allows for an error term that is not identically and independently distributed by adding a correction factor to the Dickey Fuller test statistic. A weakness of both the ADF and the PP tests is the fact that the null hypothesis is that the time series contains a unit root. Due to the dominant role of the null hypothesis in classical testing techniques an alternative is to set up a testing procedure with the null hypothesis as that of stationarity. One such test is the Kwiatkowski, Phillips, Schmidt and Shin (KPSS) (1992) test which is also applied in this paper. The application of these three testing procedures will further the robustness of any finding of a unit root in the tax rate data series and thus further the robustness of any evidence provided in support of the tax smoothing hypothesis. The first difference of the tax rate data series is also tested for the presence of a unit root to ensure there are no further roots in the data.

An oft cited criticism of unit root testing procedures is that a structural break in either the intercept or the trend in a stationary series can look like a unit root process if the structural break is not taken into account in the testing procedure. If the Maastricht Treaty and subsequent Stability and Growth Pact cause such a structural break in the tax rate time series, then the unit root testing procedures may be incorrectly indicating the presence of a unit root. To take account of the potential of this problem the Perron (1989) test incorporates the effects of a single structural break in the standard ADF unit root testing procedure. The Perron (1989) approach allows for three extensions of the standard ADF tests. These three extensions allow for a structural break in the ADF test while each 
nests the alternative hypothesis of a trend stationary process with a structural break. These three models are outlined below.

\section{Model A:}

This model tests the null hypothesis of a unit root process with trend in the presence of a change in level against the alternative hypothesis of a trend stationary process in the presence of a change in intercept.

$$
\Delta \mathrm{Y}_{\mathrm{t}}=\alpha_{0}+\lambda \mathrm{Y}_{\mathrm{t}-1}+\beta \mathrm{t}+\delta_{1} \mathrm{DVU}_{\mathrm{t}}+\delta_{2} \mathrm{DVTB}_{\mathrm{t}}+\sum_{i=1}^{k} \alpha_{\mathrm{i}} \Delta \mathrm{Y}_{\mathrm{t}-\mathrm{i}}+\varepsilon_{\mathrm{t}}
$$

Where

$\mathrm{t}=$ time trend, $\mathrm{TB}=$ time of structural break

$\mathrm{DVU}_{\mathrm{t}}=0$ if $\mathrm{t} \leq \mathrm{TB}$ and $\mathrm{DVU}_{\mathrm{t}}=1$ if $\mathrm{t}>\mathrm{TB}$

$\mathrm{DVTB}=1$ if $\mathrm{t}=\mathrm{TB}+1$ and $\mathrm{DVTB}=0$ otherwise

\section{Model B:}

This model tests the null hypothesis of a unit root process with trend in the presence of a change in growth rate against the alternative hypothesis of a trend stationary process in the presence of a change of slope.

$$
\Delta \mathrm{Y}_{\mathrm{t}}=\alpha_{0}+\lambda \mathrm{Y}_{\mathrm{t}-1}+\beta \mathrm{t}+\delta_{1} \mathrm{DVU}_{\mathrm{t}}+\delta_{3} \mathrm{DVT}_{\mathrm{t}}+\sum_{i=1}^{k} \alpha_{\mathrm{i}} \Delta \mathrm{Y}_{\mathrm{t}-\mathrm{i}}+\varepsilon_{\mathrm{t}}
$$

Where

$\mathrm{DVT}^{*}{ }_{\mathrm{t}}=0$ if $\mathrm{t} \leq \mathrm{TB}$ and $\mathrm{DVT}^{*}{ }_{\mathrm{t}}=\mathrm{t}-\mathrm{TB}$ if $\mathrm{t}>\mathrm{TB}$ 


\section{Model C:}

This model tests the null hypothesis of a unit root process with trend in the presence of a change in level and a change in growth rate against the alternative hypothesis of a trend stationary process in the presence of a change in intercept and slope.

$$
\Delta \mathrm{Y}_{\mathrm{t}}=\alpha_{0}+\lambda \mathrm{Y}_{\mathrm{t}-1}+\beta \mathrm{t}+\delta_{1} \mathrm{DVU}_{\mathrm{t}}+\delta_{2} \mathrm{DVTB}_{\mathrm{t}}+\delta_{4} \mathrm{DVT}_{\mathrm{t}}+\sum_{i=1}^{k} \alpha_{\mathrm{i}} \Delta \mathrm{Y}_{\mathrm{t}-\mathrm{i}}+\varepsilon_{\mathrm{t}}
$$

Where

$\mathrm{DVT}_{\mathrm{t}}=0$ if $\mathrm{t} \leq \mathrm{TB}$ and $\mathrm{DVT}_{\mathrm{t}}=\mathrm{t}$ if $\mathrm{t}>\mathrm{TB}$

The parameter of interest in each of these models is the $\lambda$ term. This term is used to test whether the null hypothesis of a unit root can be rejected when allowance is made for a structural break. The critical values for this t test are tabulated by Perron (1989). ${ }^{8}$

The data to be used in this study covers 12 European Union countries over the period from approximately 1970-2005 (the start date varies slightly for some countries due to data constraints). The countries examined include Austria, Belgium, Denmark, Finland, France, Germany, Ireland, Netherlands, Portugal, Spain, Sweden and the UK. Other EU countries have been omitted due to limitations in obtaining all of the necessary data. The remaining countries were selected due to the availability of the cyclical component of public expenditure

\footnotetext{
${ }^{8}$ The Zivot and Andrews (1992) unit root test in the presence of a structural break, which allows the data to select the time of the structural break, is often preferred to the Perron (1989) test. In this study the structural break is imposed to test for the effects of the Maastricht Treaty and is thus constrained to the early 1990s period using the Perron (1989) test.
} 
which was obtained from the European Commission. All public finance data is obtained at the general government level. The following section gives the results of the tests applied.

\section{Empirical Results}

This section presents the results of the testing procedures outlined in the previous section. Both the Barro regression and unit root testing procedures are applied to assess whether the sample countries were tax smoothing in the post 1970 period. A structural break is allowed for in the testing procedures in the post 1991 period to allow for the effects of the constraints imposed in the Maastricht Treaty and the subsequent Stability and Growth Pact. The application of these two tests to the same sample of countries over identical time periods will help to elucidate on the tax smoothing hypothesis clearing up some of the inconsistencies found by previous studies that used different data periods and different testing methodologies over different sample countries. Allowing for a structural break will help to establish if the Maastricht Treaty has had an effect on the behaviour of fiscal authorities in the sample countries.

The first test to be applied extends Barro's (1987) model given in equation 5.1 to a multi country setting. The model is applied to each country individually for the period 1971-2005 in most cases. ${ }^{9}$ Additional lags of the independent variable are

\footnotetext{
9 The start data is later in some countries due to the unavailability of data. The start data in Austria is 1976 due to a limitation in obtaining data on the temporary component of public expenditure. In Denmark, France, Netherlands and Portugal the start date is 1971, 1977, 1974 and 1973 respectively due to a limitation in obtaining public debt data.
} 
included to remove any serial autocorrelation. The Akaike Information Criterion and the Schwarz Bayesian Information Criterion are used to select the appropriate lag length. The appropriate lag length is denoted as $\mathrm{k}$. The regression has been estimated using heteroscedastic robust methods. The results of this regression are given in Table 1 on the following page.

Table 1: Results of the Barro regression without a structural break.

\begin{tabular}{|c|c|c|c|c|c|c|}
\hline Country & $\mathrm{k}$ & $\alpha_{0}$ & $\alpha_{1}$ & $\alpha_{2}$ & $\alpha_{2}=1^{2}$ & $\overline{R^{2}}$ \\
\hline Austria & 0 & $\begin{array}{l}5.611^{*} \\
(7.461) \\
\end{array}$ & $\begin{array}{l}-0.082 * \\
(-4.759) \\
\end{array}$ & $\begin{array}{c}11.227^{*} \\
(4.344)\end{array}$ & $15.659 *$ & 0.343 \\
\hline Belgium & 1 & $\begin{array}{l}4.254 * \\
(2.935) \\
\end{array}$ & $\begin{array}{l}-0.040^{*} \\
(-2.589) \\
\end{array}$ & $\begin{array}{c}5.903 \\
(1.056) \\
\end{array}$ & 0.770 & 0.643 \\
\hline Denmark & 1 & $\begin{array}{l}3.159^{*} \\
(2.050)\end{array}$ & $\begin{array}{l}-0.061^{*} \\
(-2.165)\end{array}$ & $\begin{array}{l}8.354^{*} \\
(3.096)\end{array}$ & $7.429 *$ & 0.617 \\
\hline Finland & 2 & $\begin{array}{l}2.609 * \\
(3.156)\end{array}$ & $\begin{array}{l}-0.064 * \\
(-2.946)\end{array}$ & $\begin{array}{l}6.380^{*} \\
(3.732)\end{array}$ & $9.905^{*}$ & 0.695 \\
\hline France & 4 & $\begin{array}{l}2.086 * \\
(2.392)\end{array}$ & $\begin{array}{c}0.002 \\
(0.114) \\
\end{array}$ & $\begin{array}{c}8.578 \\
(1.802) \\
\end{array}$ & 2.533 & 0.318 \\
\hline Germany & 0 & $\begin{array}{l}1.620 * \\
(2.245)\end{array}$ & $\begin{array}{c}-0.003 \\
0.205)\end{array}$ & $\begin{array}{c}4.910 \\
(1.745) \\
\end{array}$ & 1.931 & 0.058 \\
\hline Ireland & 1 & $\begin{array}{c}3.067 \\
(1.272)\end{array}$ & $\begin{array}{c}-0.021 \\
(-0.790)\end{array}$ & $\begin{array}{c}4.998 \\
(1.354) \\
\end{array}$ & 1.173 & 0.377 \\
\hline Netherlands & 3 & $\begin{array}{l}9.398 * \\
(4.877) \\
\end{array}$ & $\begin{array}{l}-0.122 * \\
(-4.396)\end{array}$ & $\begin{array}{c}2.093 \\
(1.982) \\
\end{array}$ & 1.072 & 0.714 \\
\hline Portugal & 0 & $\begin{array}{l}6.131 * \\
(2.982)\end{array}$ & $\begin{array}{l}-0.098 * \\
(-2.354)\end{array}$ & $\begin{array}{c}14.413 * \\
(2.110)\end{array}$ & $3.857 *$ & 0.180 \\
\hline Spain & 1 & $\begin{array}{l}2.207^{*} \\
(3.656)\end{array}$ & $\begin{array}{l}-0.044 * \\
(-2.956)\end{array}$ & $\begin{array}{l}12.642 * \\
(2.280)\end{array}$ & $4.408 *$ & 0.432 \\
\hline Sweden & 0 & $\begin{array}{l}6.704 * \\
(3.820) \\
\end{array}$ & $\begin{array}{l}-0.127 * \\
(-3.973)\end{array}$ & $\begin{array}{c}14.253 * \\
(6.906)\end{array}$ & $41.234 *$ & 0.634 \\
\hline UK & 1 & $\begin{array}{l}4.959^{*} \\
(2.969)\end{array}$ & $\begin{array}{l}-0.101 * \\
(-3.036) \\
\end{array}$ & $\begin{array}{c}3.901 \\
(1.774) \\
\end{array}$ & 1.740 & 0.555 \\
\hline
\end{tabular}

1) Regression equation given by $\left(\mathrm{b}_{\mathrm{t}}-\mathrm{b}_{\mathrm{t}-1}\right)=\alpha_{0}+\alpha_{1}\left(\mathrm{~b}_{\mathrm{t}-1}\right)+\alpha_{2} \tilde{g}_{\mathrm{t}}+\sum_{i=1}^{k} \alpha_{3 \mathrm{i}}\left(\mathrm{b}_{\mathrm{t}-\mathrm{i}}-\mathrm{b}_{\mathrm{t}-\mathrm{i}-1}\right)+\mathrm{u}_{\mathrm{t}}$

2) t-statistics on tests of the significance of the coefficients are given in parenthesis.

3) The $\chi^{2}(1)$ test tests the tax smoothing hypothesis that the $\alpha_{2}=1$.

$4) *$ denotes significance at the $5 \%$ significance level. The $5 \%$ critical value for the $\chi^{2}(1)$ is 3.841 and $t_{30}$ critical value is 2.042 .

Table 1 presents the results of tests of the tax smoothing hypothesis based upon the Barro regression over the period 1970-2005. No allowance is made here for the possible effects of the Maastricht Treaty and the subsequent Stability and Growth Pact. The explanatory power of the regression is quite low in some countries, particularly in Germany and Portugal, indicating that the regression 
does not offer a good explanation of the fiscal deficit. The $\overline{R^{2}}$ is above 0.6 in only five of the twelve countries. The parameter of interest with regards to the tax smoothing hypothesis is the $\alpha_{2}$ term, the coefficient on the cyclical component of public expenditure. Support for the tax smoothing hypothesis requires that this term is equal to or close to unity. A $\chi^{2}$ (1) test is used to test the hypothesis that this coefficient is equal to unity. The tax smoothing hypothesis cannot be rejected in half the sample countries, including Belgium, France, Germany, Ireland, Netherlands and the UK.

In all of the countries where the tax smoothing hypothesis is rejected the coefficient on the $\alpha_{2}$ term is actually greater than unity. This may be caused by several factors. Firstly, any value greater than one on the cyclical component of public expenditure may indicate a tendency to lower taxes during a recession, possibly as the result of counter cyclical fiscal policies. Secondly, the coefficient may be greater than unity because cyclical fluctuations in the temporary public expenditure term tend to coincide with contrary temporary shocks to tax revenues. A final reason for the high value on the coefficient on the cyclical component of public expenditure term may be due to a weakness in the construction of the temporary spending variable or to a weakness in the specification in the regression equation.

One possible weakness in the specification of the regression equation is that it does not allow for the possibility of a structural break in the tax smoothing relation which may have occurred due to the imposition of the constraint of the Maastricht Treaty and the subsequent Stability and Growth Pact. This constraint may result in fiscal authorities moving away from a policy of tax smoothing to 
more active fiscal policy management. To allow for this possibility two dummy variables are included in equation 1 . These dummy variables allow for structural change in the intercept term and in the slope coefficient on the cyclical component of public expenditure term. The results of this regression are given in Table 2 on the following page. The regression is estimated using heteroscedastic robust methods along with $\mathrm{k}$ lags of the dependent variable to remove any serial autocorrelation. 
Table 2: Results of the Barro regression with a structural break.

\begin{tabular}{|c|c|c|c|c|c|c|c|c|c|c|c|}
\hline Country & $\begin{array}{c}\text { Structural } \\
\text { Break }\end{array}$ & $\mathrm{k}$ & $\alpha_{0}$ & $\mathrm{~d}_{1}$ & $\alpha_{1}$ & $\alpha_{2}$ & $\mathrm{~d}_{2}$ & $\mathrm{~d}_{1}=\mathrm{d}_{2}=0$ & $\alpha_{2}=1$ & $\alpha_{2}+d_{2}=1$ & $\overline{R^{2}}$ \\
\hline Austria & 1991 & 0 & $\begin{array}{c}8.024^{*} \\
(6.850) \\
\end{array}$ & $\begin{array}{c}2.300 * \\
(2.487) \\
\end{array}$ & $\begin{array}{l}-0.151 * \\
(-5.512) \\
\end{array}$ & $\begin{array}{l}19.671^{*} \\
(4.334) \\
\end{array}$ & $\begin{array}{c}-2.938 \\
(-0.388) \\
\end{array}$ & $9.218^{*}$ & $16.923 *$ & $5.284 *$ & 0.370 \\
\hline Belgium & 1994 & 1 & $\begin{array}{l}3.873^{*} \\
(2.727) \\
\end{array}$ & $\begin{array}{l}-3.235^{*} \\
(-2.323) \\
\end{array}$ & $\begin{array}{c}-0.022 \\
(-1.189) \\
\end{array}$ & $\begin{array}{c}9.712 \\
(1.664) \\
\end{array}$ & $\begin{array}{l}-11.828 \\
(-0.860) \\
\end{array}$ & $6.663^{*}$ & 2.228 & 0.060 & 0.678 \\
\hline Denmark & 1994 & 1 & $\begin{array}{l}3.588^{*} \\
(2.159) \\
\end{array}$ & $\begin{array}{l}-3.695^{*} \\
(-2.907) \\
\end{array}$ & $\begin{array}{c}-0.046 \\
(-1.651) \\
\end{array}$ & $\begin{array}{l}10.891 * \\
(3.482) \\
\end{array}$ & $\begin{array}{c}-12.337^{*} \\
(-2.925) \\
\end{array}$ & $13.283 *$ & $10.002 *$ & 0.673 & 0.718 \\
\hline Finland & 1991 & 2 & $\begin{array}{l}3.2741^{*} \\
(7.206)\end{array}$ & $\begin{array}{l}5.453^{*} \\
(4.592) \\
\end{array}$ & $\begin{array}{l}-0.199 * \\
(-6.388) \\
\end{array}$ & $\begin{array}{l}3.176^{*} \\
(4.632) \\
\end{array}$ & $\begin{array}{c}11.763^{*} \\
(5.150)\end{array}$ & $154.260 *$ & $10.074 *$ & $29.004 *$ & 0.912 \\
\hline France & 1991 & 4 & $\begin{array}{l}6.192 * \\
(8.905) \\
\end{array}$ & $\begin{array}{l}3.901 * \\
(6.931) \\
\end{array}$ & $\begin{array}{l}-0.107 * \\
(-5.433) \\
\end{array}$ & $\begin{array}{l}4.114 * \\
(2.366) \\
\end{array}$ & $\begin{array}{c}27.174 * \\
(6.647) \\
\end{array}$ & $64.871 *$ & 3.208 & $42.649 *$ & 0.787 \\
\hline Germany & 1991 & 0 & $\begin{array}{l}4.370^{*} \\
(3.428)\end{array}$ & $\begin{array}{l}3.711^{*} \\
(2.784) \\
\end{array}$ & $\begin{array}{l}-0.108^{*} \\
(-2.629) \\
\end{array}$ & $\begin{array}{c}9.387 \\
(1.796) \\
\end{array}$ & $\begin{array}{c}0.314 \\
(0.058) \\
\end{array}$ & $10.238 *$ & 2.575 & $6.981 *$ & 0.260 \\
\hline Ireland & 1992 & 1 & $\begin{array}{c}5.323 \\
(1.841) \\
\end{array}$ & $\begin{array}{c}-6.263 \\
(-1.486) \\
\end{array}$ & $\begin{array}{c}-0.043 \\
(-1.401) \\
\end{array}$ & $\begin{array}{c}2.215 \\
(0.664) \\
\end{array}$ & $\begin{array}{c}-3.601 \\
(-0.444)\end{array}$ & $6.167 *$ & 0.133 & 0.081 & 0.401 \\
\hline Netherlands & 1993 & 3 & $\begin{array}{l}13.051^{*} \\
(7.093) \\
\end{array}$ & $\begin{array}{c}-2.561 \\
(-1.648) \\
\end{array}$ & $\begin{array}{l}-0.090 * \\
(-3.972) \\
\end{array}$ & $\begin{array}{l}5.435^{*} \\
(5.846) \\
\end{array}$ & $\begin{array}{c}2.905 \\
(1.883) \\
\end{array}$ & $37.746^{*}$ & $22.758 *$ & $18.509 *$ & 0.829 \\
\hline Portugal & 1991 & 0 & $\begin{array}{l}6.323^{*} \\
(3.182) \\
\end{array}$ & $\begin{array}{c}0.277 \\
(0.225) \\
\end{array}$ & $\begin{array}{l}-0.105^{*} \\
(-2.351) \\
\end{array}$ & $\begin{array}{l}16.843 \\
(1.565) \\
\end{array}$ & $\begin{array}{c}-4.720 \\
(-0.346) \\
\end{array}$ & 0.184 & 2.166 & 2.063 & 0.123 \\
\hline Spain & 1994 & 1 & $\begin{array}{c}0.070 \\
(0.894) \\
\end{array}$ & $\begin{array}{l}-5.087 * \\
(-2.767) \\
\end{array}$ & $\begin{array}{c}0.053 \\
(1.247) \\
\end{array}$ & $\begin{array}{c}21.409^{*} \\
(4.726) \\
\end{array}$ & $\begin{array}{c}4.122 \\
(0.469) \\
\end{array}$ & $9.831 *$ & $20.296 *$ & $11.140^{*}$ & 0.501 \\
\hline Sweden & 1992 & 0 & $\begin{array}{l}5.802 * \\
(3.678)\end{array}$ & $\begin{array}{c}-2.281 \\
(-2.014)\end{array}$ & $\begin{array}{l}-0.097 * \\
(-3.111)\end{array}$ & $\begin{array}{c}12.459^{*} \\
(5.981)\end{array}$ & $\begin{array}{c}7.915 \\
(1.886)\end{array}$ & $6.294 *$ & $30.262^{*}$ & $27.824^{*}$ & 0.675 \\
\hline UK & 1991 & 1 & $\begin{array}{c}1.805 \\
(0.697) \\
\end{array}$ & $\begin{array}{l}4.503^{*} \\
(3.589) \\
\end{array}$ & $\begin{array}{c}-0.052 \\
(-1.169) \\
\end{array}$ & $\begin{array}{l}4.688 \\
(1.90) \\
\end{array}$ & $\begin{array}{c}36.335^{*} \\
(5.821) \\
\end{array}$ & $33.899 *$ & 2.234 & $34.619 *$ & 0.617 \\
\hline
\end{tabular}

1) Regression equation given by $\left(\mathrm{b}_{\mathrm{t}}-\mathrm{b}_{\mathrm{t}-1}\right)=\alpha_{0}+\mathrm{d}_{1}+\alpha_{1}\left(\mathrm{~b}_{\mathrm{t}-1}\right)+\alpha_{2} \tilde{g}_{\mathrm{t}}+\mathrm{d}_{2} \tilde{g}_{\mathrm{t}}+\sum_{i=1}^{k} \alpha_{3 \mathrm{i}}\left(\mathrm{b}_{\mathrm{t}-\mathrm{i}}-\mathrm{b}_{\mathrm{t}-\mathrm{i}-1}\right)+\mathrm{u}_{\mathrm{t}}$

2) Both $\mathrm{d}_{1}$ and $\mathrm{d}_{2}$ are $=0$ if $\mathrm{t}<=$ structural break and 1 otherwise.

3) t-statistics are given in parenthesis. The $t_{30}$ critical value is $2.042 . \chi^{2}(1)$ is used to test the tax smoothing hypothesis that $\alpha_{2}=1$ and also that $\alpha_{2}+d_{2}=1 . \chi^{2}$ (2) is used to test the hypothesis that $\mathrm{d}_{1}=\mathrm{d}_{2}=0$.The $5 \%$ critical value is 3.841 for $\chi^{2}(1)$ and 5.99 for $\chi^{2}(2)$. * denotes significance at the $5 \%$ significance level. 
Table 2 presents the results of the Barro regression tests of the tax smoothing hypothesis over the sample period, allowing for a structural break due to the Maastricht Treaty. Allowance for a structural break is made by including an intercept dummy variable $\left(\mathrm{d}_{1}\right)$ and a slope dummy variable $\left(\mathrm{d}_{2}\right)$ on the cyclical component of public expenditure term in the regression. Both dummy variables take on a value of zero from 1970 to the structural break, and a value of one thereafter. A structural break is first tested for in 1991. For the countries in which this is found not to be significant the structural break is recursively rolled forward until 1995. For countries in which a structural break is not significant the results are shown for the insignificant structural break in 1991.

The allowance for a structural break has improved the explanatory power of the regression in almost all countries. The $\overline{R^{2}}$ is now greater than 0.6 in seven of the twelve countries. To test whether the structural break is statistically significant a $\chi^{2}(2)$ test is applied to test the null hypothesis that the intercept and the slope dummy variables are jointly equal to zero. A structural break, occurring between 1991 and 1994, is found to be statistically significant at the 5\% level in almost all countries, with the exception Portugal. This indicates that a structural break occurs in nearly all countries in the relationship between the fiscal deficit and the cyclical component of public expenditure. The timing of the structural break coincides with the imposition of the fiscal constraints of the Maastricht Treaty. The question remains as to how the change in behaviour affects evidence of tax smoothing behaviour. 
The parameters of interest with regards to the tax smoothing hypothesis are the $\alpha_{2}$ coefficient on the cyclical component of public expenditure term and the $d_{2}$ slope dummy variable on the cyclical component of public expenditure. When allowance is made for a structural break, support for the tax smoothing hypothesis now requires that $\alpha_{2}=1$ in the pre structural break period and that $\alpha_{2}$ $+\mathrm{d}_{2}=1$ in the post structural break period. The results in Table 2 above show that the hypothesis that $\alpha_{2}=1$ cannot be rejected in half of the sample countries including Belgium, France, Germany, Ireland, Portugal and the UK. This is evidence that the tax smoothing hypothesis is supported in these countries prior to the effects of the Maastricht Treaty. The results in Table 2 also show that the hypothesis that $\alpha_{2}+d_{2}=1$ cannot be rejected in only four of the twelve countries including Belgium, Denmark, Ireland and Portugal, showing less support for the tax smoothing hypothesis in the post Maastricht period.

The evidence presented thus far indicates that the Maastricht Treaty does indeed result in a structural break in the relationship between the temporary component of public expenditure and the fiscal deficit. In tests of the tax smoothing hypothesis, taking account of the structural break reduces the number of countries which show support for the tax smoothing hypothesis. France, Germany and the UK no longer show support for the tax smoothing hypothesis after the Maastricht Treaty where as they did show support for the tax smoothing hypothesis prior to the Treaty. The evidence in Portugal suggests that the Maastricht Treaty resulted in a movement towards tax smoothing behaviour. Although this evidence is weakened by the observation that Portugal is the only 
country in which a structural break is not significant. When the structural break is excluded Portugal shows no evidence in support of the tax smoothing hypothesis.

Overall the results from the Barro regressions show that the Maastricht Treaty matters. The Maastricht Treaty results in some movement away from tax smoothing behaviour. Only six of the twelve countries show support for the tax smoothing hypothesis prior to the Maastricht Treaty, after the Maastricht Treaty support for the tax smoothing hypothesis is provided in only three countries. Taking both periods together the post 1970 cross country sample indicates that whereas there is some evidence of tax smoothing behaviour there are significant departures. Those departures are much more prevalent in the post Maastricht period.

One of those reasons given for the high value that is observed on the cyclical component of public expenditure coefficient is that it may be as a result of a weakness in the construction of the cyclical component of public expenditure term. A more direct means to test the tax-smoothing hypothesis which is not affected by the accuracy of the measure the cyclical component of public expenditure is to test if the tax rate time series contains a unit root. To test for a unit root the augmented Dickey Fuller (ADF), Phillips Perron (PP) and Kwiatkowski, Phillips, Schmidt and Shin (KPSS) unit root testing procedures have been applied. These three testing procedures are applied together to further the robustness of any findings. To take account of any possible structural break in the time series the Perron (1989) unit root testing method is also applied. This approach takes account of the effects of a structural break in the unit root tests in 
the ADF equations. The results of the ADF, PP and KPSS unit root tests without

taking account of a possible structural break are given in Table 3 below.

Table 3: Unit root test results on the tax rate time series using the Augmented Dickey Fuller test, the Phillips Perron test and the KPSS test for the period 1970-2005.

\begin{tabular}{|c|c|c|c|}
\hline \multicolumn{4}{|c|}{ Augmented Dickey Fuller tests } \\
\hline Country & Model with constant & $\begin{array}{l}\text { Model with constant } \\
\text { and time trend }\end{array}$ & $\begin{array}{l}\text { Model with first } \\
\text { differences }\end{array}$ \\
\hline Austria & $-2.993 *$ & -0.885 & $-3.540 *$ \\
\hline Belgium & -2.448 & -2.176 & $-5.780 *$ \\
\hline Denmark & -1.450 & -1.528 & $-4.165 *$ \\
\hline Finland & -2.354 & -1.509 & $-4.765 *$ \\
\hline France & -1.898 & -1.266 & $-4.707 *$ \\
\hline Germany & $-3.550 *$ & -2.766 & $-5.448 *$ \\
\hline Ireland & -1.709 & -1.251 & $-6.282 *$ \\
\hline Netherlands & -2.374 & -2.576 & $-4.725 *$ \\
\hline Portugal & -0.670 & $-3.521 *$ & $-6.471 *$ \\
\hline Spain & -1.963 & -0.411 & $-4.791 *$ \\
\hline Sweden & -2.727 & -1.707 & -2.720 \\
\hline UK & $-2.967 *$ & -3.483 & $-2.967 *$ \\
\hline \multicolumn{4}{|c|}{ Phillips Perron test ( $1=3$ in all cases $)$} \\
\hline Country & Model with constant & $\begin{array}{l}\text { Model with constant } \\
\text { and time trend }\end{array}$ & $\begin{array}{c}\text { Model with first } \\
\text { differences }\end{array}$ \\
\hline Austria & $-3.125^{*}$ & -0.713 & $-4.795 *$ \\
\hline Belgium & -2.549 & -2.280 & $-5.969 *$ \\
\hline Denmark & -1.483 & -1.853 & $-6.543 *$ \\
\hline Finland & -2.506 & -1.512 & $-4.857 *$ \\
\hline France & -1.892 & -1.416 & $-4.919 *$ \\
\hline Germany & $-3.611 *$ & -2.896 & $-5.617 *$ \\
\hline Ireland & -1.785 & -1.287 & $-6.440 *$ \\
\hline Netherlands & -2.429 & -2.771 & $-4.871 *$ \\
\hline Portugal & -0.598 & $-3.582 *$ & $-5.674 *$ \\
\hline Spain & -1.828 & -0.637 & $-5.050 *$ \\
\hline Sweden & -2.870 & -1.732 & $-4.918 *$ \\
\hline UK & -2.653 & -2.692 & $-4.336^{*}$ \\
\hline
\end{tabular}


Table 3 Continued.

\begin{tabular}{|l|c|c|c|}
\hline \multicolumn{1}{|c|}{ Kountry } & Model with constant & $\begin{array}{c}\text { Model with constant } \\
\text { and time trend }\end{array}$ & $\begin{array}{c}\text { Model with first } \\
\text { differences }\end{array}$ \\
\hline Austria & $0.676^{*}$ & $0.239^{*}$ & $0.639^{*}$ \\
\hline Belgium & $0.764^{*}$ & $0.148^{*}$ & 0.250 \\
\hline Denmark & $0.865^{*}$ & $0.195^{*}$ & 0.149 \\
\hline Finland & $0.839^{*}$ & $0.203^{*}$ & 0.334 \\
\hline France & $0.836^{*}$ & $0.211^{*}$ & 0.249 \\
\hline Germany & 0.291 & 0.103 & 0.339 \\
\hline Ireland & 0.368 & $0.230^{*}$ & 0.279 \\
\hline Netherlands & 0.233 & $0.230^{*}$ & 0.459 \\
\hline Portugal & $0.987^{*}$ & 0.115 & 0.088 \\
\hline Spain & $0.877^{*}$ & $0.232^{*}$ & 0.367 \\
\hline Sweden & $0.678^{*}$ & $0.231^{*}$ & 0.411 \\
\hline UK & $0.478^{*}$ & 0.088 & 0.098 \\
\hline
\end{tabular}

1) The lag length for the ADF tests is selected using the LM and the BIC.

2) The lag truncation parameter in the PP and KPSS tests is set at $1=T^{1 / 3}$ as recommended by Andrews (1991, cited in Patterson 2000).

3 * denotes significance at the 5\% level. The 5\% critical values for the test statistics are as follows: The ADF with constant is 2.93, with constant and time trend is 3.50, and in first differences is 2.93 . The Phillips Perron with constant is 2.945 , with constant and time trend is 3.539 and in first differences is 2.947 . The KPSS with constant is 0.463 , with constant and time trend is 0.146 and in first differences is 0.463 .

The results of the ADF and PP unit root tests in Table 3 indicate that the null hypothesis of a unit root in the tax rate time series cannot be rejected in most cases when a time trend is either included or excluded. This lends strong support to the tax smoothing hypothesis. The null hypothesis of a unit root is rejected in Austria and Germany when a time trend is excluded and in Portugal when a time trend is included. Additionally the ADF test also rejects the null hypothesis of a unit root in the UK.

Due to the effects of the dominant role of the null hypothesis in testing procedures the KPSS unit root test is also applied. This test is set up such that the null hypothesis is that of stationarity. The results of this test, also given in Table 3 above, are again supportive of the tax smoothing hypothesis in most countries. In Germany, Ireland and the Netherlands there is, however, no evidence of a unit root when a time trend is excluded. Additionally there is also no evidence of a 
unit root in Germany, Portugal, and the UK when a time trend is included. The first differences of the data series are found to be stationary across the three testing procedures in most cases, with the exception of Sweden under the ADF test and in Austria according to the KPSS test. This shows little evidence of more than one root in the tax rate data series. Overall the unit root testing procedures are generally supportive of the tax smoothing hypothesis in most countries.

One limitation of the above unit root tests is that they are biased towards identifying a unit root if the series is stationary with a structural break. The structural break may result in the non rejection of the null hypothesis of a unit root when the alternative is true for any of the following three reasons. Firstly, the series may be trend stationary with a one time change in the level. Secondly, the series may be trend stationary with a change in the trend slope (growth rate). Thirdly the series may be trend stationary with a change in both the level and the trend slope. If any of these three scenarios capture the true data generating process then the unit root process is biased towards the non rejection of a unit root. Perron (1989) suggests three models as outlined earlier to allow for the above three scenarios. Table 4 below presents the results of these tests for a unit root in each of the three models allowing for a structural break. The Perron (1989) test was conducted for all countries allowing for a structural break in each of the years 1991-1994 inclusive. Table 4 on the following page shows a selection of these results. 
Table 4: Perron unit root tests allowing for a structural break in the Augmented Dickey Fuller regressions.

\begin{tabular}{|l|l|l|c|c|c|c|c|}
\hline & & \multicolumn{2}{|c|}{ Model A } & \multicolumn{2}{c|}{ Model B } & \multicolumn{2}{|c|}{ Model C } \\
\hline Country & $\begin{array}{l}\text { Structural } \\
\text { Break }\end{array}$ & $\mathrm{k}$ & $\begin{array}{c}\text { Unit root test } \\
\text { statistic }\end{array}$ & $\mathrm{k}$ & $\begin{array}{c}\text { Unit root test } \\
\text { statistic }\end{array}$ & $\mathrm{k}$ & $\begin{array}{c}\text { Unit root test } \\
\text { statistic }\end{array}$ \\
\hline Austria & 1991 & 0 & -0.887 & 0 & -1.652 & 0 & -1.321 \\
\hline Belgium & 1991 & 0 & -1.447 & 0 & -1.381 & 0 & -1.445 \\
\hline Denmark & 1991 & 0 & -1.646 & 0 & -2.856 & 0 & -2.482 \\
\hline Finland & 1991 & 0 & -1.804 & 0 & -2.945 & 0 & -2.876 \\
\hline France & 1991 & 0 & -1.051 & 1 & -1.316 & 0 & -1.125 \\
\hline Germany & 1991 & 0 & -2.718 & 0 & -3.184 & 0 & -2.927 \\
\hline Ireland & 1991 & 0 & -1.950 & 0 & -2.803 & 0 & -2.690 \\
\hline Netherlands & 1992 & 0 & $-4.080^{*}$ & 0 & -1.875 & 0 & -2.403 \\
\hline Portugal & 1991 & 1 & $-5.030^{*}$ & 1 & $-6.712^{*}$ & 1 & $-6.250^{*}$ \\
\hline Spain & 1993 & 1 & -3.456 & 1 & $-3.937^{*}$ & 0 & $-5.243^{*}$ \\
\hline Sweden & 1991 & 0 & -1.356 & 0 & -2.171 & 0 & -2.367 \\
\hline UK & 1991 & 1 & $-4.141^{*}$ & 1 & $-4.716^{*}$ & 1 & $-4.539^{*}$ \\
\hline
\end{tabular}

1) Perron (1989) test for a unit root is given for each of the three models A, B \& C.

2) The appropriate lag length is chosen for the autoregressive process by adding lags until the LM statistic fails to reject no serial autocorrelation.

3 ) The $5 \%$ critical values for the test statistic as tabulated by Perron (1989). The critical values when the structural break is in 1991 in model A is 3.76, the critical value in model B is 3.95 and the critical value in model $\mathrm{C}$ is 4.24 . The critical values when the structural break is later than 1991 in Model A is 3.80, in Model B 3.85 and in Model C is 4.18.

Table 4 gives the results of the three unit root tests as outlined by Perron (1989) for the test of the null hypothesis that the tax rate time series contains a unit root when allowance is made for a structural break. The parameter of interest in testing the null hypothesis of a unit root is the $\mathrm{t}$ test statistic on the $\mathrm{Y}_{\mathrm{t}-1}$ term. A structural break is applied recursively between the years 1991-1994 to establish if it affects the results of the null hypothesis that the tax rate time series contains a unit root. The results in Table 4 show that the null hypothesis of a unit root, when allowance is made for a structural break, cannot be rejected in nine out of the 12 countries across all three of the Perron (1989) models. This includes Austria, Belgium, Denmark, Finland, France Germany, Ireland, Italy, and Sweden. Table 4 gives the Perron (1989) test statistic for these countries allowing for a structural break in 1991. This result holds when a structural break is allowed in each of the years 1991-1994. In the remaining three countries, either one or more of the Perron (1989) models reject the null hypothesis of a 
unit root when a structural break is allowed at some point between 1991 and 1994. The results in Table 4 show that the null hypothesis of a unit root is rejected in the UK and Portugal when a structural break is allowed in 1991 across all three models. The null hypothesis of a unit root is also rejected in the Netherlands when a structural break is allowed in 1992 in model A, in Spain in 1993 when a structural break is allowed in 1993 in model B.

Comparing the results from Table 4 above with those from the augmented Dickey Fuller tests given in Table 3 allows for an assessment to be made regarding the effects of the Maastricht Treaty on the evidence in support of the tax smoothing hypothesis. The Augmented Dickey Duller test results provide a consistent comparison as the Perron (1989) tests amount to the inclusion of a structural break in the Augmented Dickey and Fuller tests. The null hypothesis of a unit root is rejected in four countries, including the Netherlands, Portugal, Spain ant the UK when a structural break is included in the test. The null hypothesis of a unit root is rejected in only four countries, including Austria, Germany, Portugal and the UK, when a structural break is not included. In the countries where the null hypothesis of a unit root is rejected, only two countries consistently reject the hypothesis both with and without the inclusion of a structural break. The question as to whether the Maastricht Treaty affects the support for the tax smoothing hypothesis is, according to the unit root tests is not convincing. 


\section{Conclusion}

The purpose of this paper is to investigate whether there is evidence of tax smoothing in 12 European Union countries in the post 1970 period. Previous studies have found conflicting evidence as to whether there is evidence of tax smoothing over a range of different countries, over different sample periods, using a number of different testing methodologies. This present paper applies two different testing methodologies over a single sample of European Union countries to establish the evidence in support of the tax smoothing hypothesis. The first testing method applies a regression equation similar to that put forward by Barro (1979, 1986 and 1987). The second testing method involves applying three unit root testing procedures to establish if the tax rate time series contains a unit root and thus provides evidence of tax smoothing behaviour.

The agreement of the Maastricht Treaty and subsequent Stability and Growth Pact in most of the sample countries constitutes the imposition of a supranational budgetary constraint. This constraint influences fiscal policy and has implications for evidence of tax smoothing behaviour. Therefore the tests applied in this study allow for a structural break to take account of this constraint. A finding that a structural break occurs provides support for the hypothesis that the constraint matters. The effects of the constraint on tax smoothing behaviour are also analysed.

Overall the evidence presented reflects that some of the results obtained are sensitive to the testing method employed. Over the full period, without taking 
account for a structural break, the null hypothesis that countries are tax smoothing cannot be rejected in about half of the countries. This shows that while there is some evidence of support for the tax smoothing hypothesis, there are significant deviations from this policy. One possible explanation for these departures investigated here is due to budgetary institutions. The evidence suggests that the Maastricht Treaty resulted in a structural break in the behaviour of fiscal authorities in all countries except Portugal. There is also evidence that the Maastricht Treaty resulted in a movement away from tax smoothing policies in some countries. Although this evidence of the effects of the Maastricht Treaty on tax smoothing behaviour is again sensitive to the testing procedure applied. 


\section{References}

Alesina A, Perotti R., 1995. The Political Economy of Budget Deficits. IMF Staff Papers 1995;42(1); 1-31.

Alesina A, Perotti R., 1999. Budget Deficits and Budget Institutions. In Poterba J, von Hagen $\mathrm{J}$ (EDS), Fiscal Institutions and Fiscal Performance. A NBER Conference Report. University of Chicago Press, Chicago; 1999. pp. 13-36.

Ballabriga FC, Martinez-Mongay C., 2005. Sustainability of EU Public Finances. European Economy, Economic Papers 2005;225.

Barro R., 1979. On the Determination of Public Debt. Journal of Political Economy 1979;87(5); 940-71.

Barro R., 1986. US Deficits since World War I. Scandinavian Journal of Economics 1986;88(1); 198-222.

Barro R., 1987. Government Spending, Interest Rates, Prices, and Budget Deficits in the United Kingdom 1701-1918. Journal of Monetary Economics $1987 ; 20(2) ; 221-247$.

Barro R., 1989. The Ricardian Approach to Budget Deficits. Journal of Economic Perspectives 1989;3(20); 32-54. 
Considine J, Duffy D., 2006. Partially Sighted Persons and the Public Debt Elephant. Constitutional Political Economy 2006;17(4): 237-49.

Cooley T, Ohanian L., 1997. Postwar British Economic Growth and the Legacy of Keynes. Journal of Political Economy 1997;105(3) 439-472.

European Commission 2001. Public Finance in EMU- 2001. European Economy, Reports and Studies 2001;3.

Gupta K., 1992. Optimal Taxation Policy: Evidence from Canada. Public Finance 1992;47; 193-200.

Kwiatkowski D, Phillips P, Schmidt P, Shin Y., 1992. Testing the Null Hypothesis of Stationarity against the Alternative of a Unit Root. Journal of Econometrics 1992;54; 159-178.

Modigliani F, 1986. Comment on R.J.Barro, U.S. Deficits Since World War I. Scandinavian Journal of Economics 1986;88(1); 223-234.

Patterson K, 2000. An Introduction to Applied Econometrics. MacMillan Press, London; 2000.

Perron P, 1989. The Great Crash, the Oil Price Shock, and the Unit Root Hypothesis. Econometrica 1989;57(6) 1361-1401. 
Phillips P, Perron P., 1988. Testing for a Unit Root in time Series Regression. Biometrica 1988;75; 335-46.

Romer D, 2001. Advanced Macroeconomics $2^{\text {nd }}$ Edition. McGraw-Hill, New York; 2001.

Roubini N, Sachs J., 1989. Political and Economic Determinants of Budget Deficits in the Industrial Democracies. European Economic Review 1989;33(5); 903-933.

Sahasakul C, 1986. The US Evidence on Optimal Taxation over Time. Journal of Monetary Economics 1986;18(3); 251-75.

Strazicich M, 2002. International Evidence of Tax Smoothing in a Panel of Industrial Countries. Applied Economics 2002;34(18); 2325-2331.

Zivot E, Andrews D. 1992. Further evidence on the Great Crash, the oil price shock, and the unit-root hypothesis. Journal of Business and Economic Statistics $1992 ; 10(3) ; 251-70$. 